\title{
Complementary Reactivity of 1,6-Enynes with All-Metal Aromatic Trinuclear Complexes and Carboxylic Acids
}

\author{
Chiara Cecchini ${ }^{\mathrm{a}}$ \\ Matteo Lanzi ${ }^{a}$ \\ Gianpiero Cera ${ }^{a}$ \\ Max Malacria*b (iD) \\ Giovanni Maestri*a (D) \\ a Università di Parma, Dipartimento di Scienze Chimiche, della Vita e \\ della Sostenibilità Ambientale, 17/A Parco Area delle Scienze, 43124 \\ Parma, Italy \\ giovanni.maestri@unipr.it \\ b UPMC Sorbonne Université, IPCM (UMR CNRS 8232), 4 place Jussieu, \\ C. 229, 75005 Paris, France \\ max.malacria@upmc.fr
}

Published as part of the 50 Years SYNTHESIS - Golden Anniversary Issue
Received: 30.11 .2018

Accepted: 18.12 .2018

Published online: 18.01 .2019

DOI: 10.1055/s-0037-1611653; Art ID: ss-2018-z0806-fa

License terms: CCO

Abstract The distinct reactivity of 1,6-enynes in the presence of a trinuclear metal complex activated by a carboxylic acid is presented. The triplatinum catalyst enables the cyclization of the substrate and subsequent incorporation of a nucleophile in the final product. In contrast, sequential cyclization/double bond shift occurs under analogous conditions in the presence of the corresponding tripalladium complex.

Key words enynes, palladium, platinum, clusters, aromaticity, cyclization

All-metal aromatic clusters represent an intriguing class of organometallic molecules characterized by delocalized metal-metal bonds, which parallel their classical carbonbased counterparts. ${ }^{1}$ Thanks to the variety of electronic states offered by metal atoms compared to main group elements, it has been possible to push the known boundaries of chemical bonding in the last two decades. ${ }^{2}$ This includes rather exotic molecular orbitals ones such as $\delta$ - and $\varphi$-type bonds, ${ }^{3}$ which cannot be observed in carbon-based molecules, as well as examples of multidimensional electronic delocalization that crumpled the traditionally flat landscape of regular aromatic rings. ${ }^{4}$ However, while an ample mix of fascinating structures has been reported both at the molecular level and in material sciences, their limited bench stability has for a long time hampered thoughtful study of the consequences of this bonding mode on organic synthesis. ${ }^{1-4}$

Very recently, our group established a straightforward synthetic approach for the synthesis of all-5d $\mathrm{M}_{3}{ }^{+}$metal aromatic complexes, whose synthesis is robust and can be accomplished in a modular fashion (Scheme 1). ${ }^{5}$ The reaction uses a zero-valent palladium or platinum complex, a tertia-

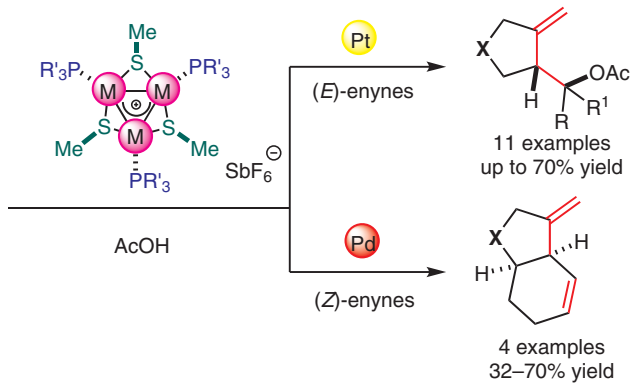

ry phosphine, and a disulfide in the presence of a redox active chlorinated solvent to afford the desired $C_{3}$-symmetric trinuclear cluster. These complexes can be crystalized upon anion metathesis with a suitable silver salt, providing a bench- and air-stable tool for further synthetic purposes.

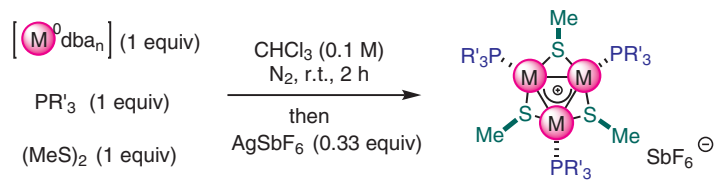

$$
\begin{array}{ll}
\text { M }=P t, R^{\prime}=p-T o l & \text { (A): } 30 \% \\
M=P d, R^{\prime}=P h & \text { (B): } 97 \%
\end{array}
$$
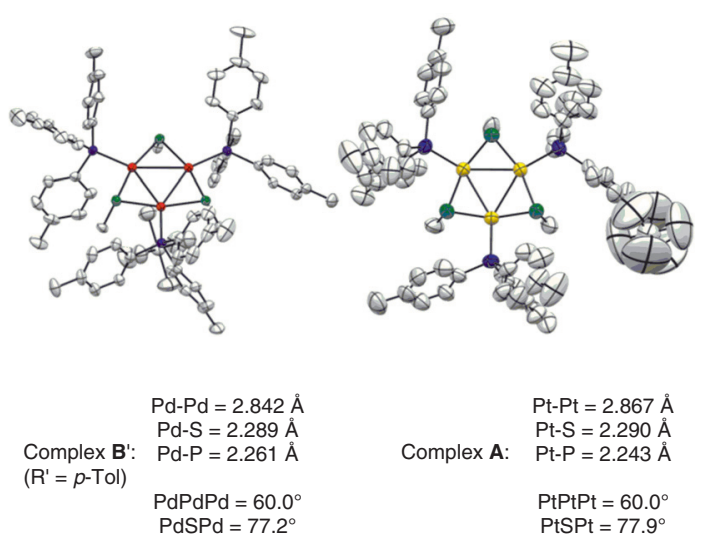

Scheme 1 One-pot synthesis of trinuclear $\mathrm{M}_{3}{ }^{+}$complexes used in this study and comparison of their main structural features at the solid state

This method allowed for a rapid yet still open investigation on the reactivity of these clusters as powerful catalysts in synthetic organic transformations. Particularly, trinuclear palladium complexes were reported to promote highly efficient semi-reduction of alkynes under hydrogen-trans- 


Chiara Cecchini obtained her transition metal-oxo complexes in the laboratory of Prof.
master degree in Industrial under the supervision of Prof. Giovanni Maestri. Her current
Chemistry in 2016 at the Uni-
versity of Bologna. She studied mo Zacchini. She then work focuses on transition-met-
the biorelevant activity of late

Matteo Lanzi obtained his M.Sc. in Industrial Chemistry at the University of Parma in 2014. He then joined the group of $G$. Maestri at the University of Par-

Gianpiero Cera studied chemistry at the University of Bologna and completed his Ph.D. there in 2014 with Prof. M. Bandini working on gold-catalysis. During this period, he spent six months in the group of Prof.

Max Malacria obtained his Ph.D. from the University of AixMarseille III with Prof. Marcel Bertrand. He was appointed as Assistant in 1974 at the University of Lyon I with Prof. J. Goré. After almost two years as a postdoctoral fellow with Prof. K.

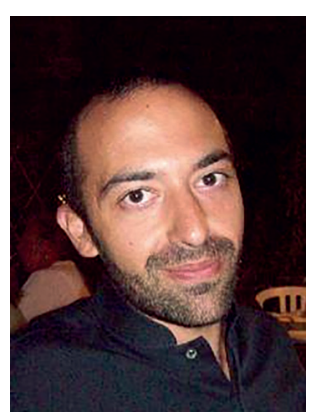

Giovanni Maestri obtained his Ph.D. from the University of Parma under the guidance of Prof. Marta Catellani. In 2011, he began a postdoc stay at UPMC with Louis Fensterbank and Emmanule Lacote and then ma, where he is currently completing his Ph.D. thesis. During this period he studied catalytic methods to attain molecular complexity via domino reac- tions and he spent a research stay at ICSN with Géraldine Masson, working on novel photocatalyzed reactions.
D. Toste at the University of California, Berkeley (Marco Polo fellow). He then moved to the group of Prof. L. Ackermann at the Georg-August-Universität, Göttingen as an AVH fellow, working on $\mathrm{C}-\mathrm{H}$ functionaliza- tions. He is currently a postdoctoral researcher at the University of Parma with Prof. G. Maestri. His main research activities regard the development of metal-catalyzed alkynes functionalizations.
P. C. Vollhardt at Berkeley, he went back to the University of Lyon as Maître de Conférences in 1983. In 1988, he was appointed as Full Professor at the UPMC. In 1991, he was elected junior member of the Institut Universitaire de France and pro- moted to senior member in 2001. He directed the ICSN in Gif sur Yvette from 2011 to 2015 and he is now member of the European Academy of Sciences. followed Max Malacria at ICSN as post-doctoral researcher in 2012. In 2014, he moved back to his Alma Mater, first recruited as Assistant Professor and currently serving as tenured Professor. His main interests swirl around various aspects of organometallic chemistry, from catalytic synthesis through cascades to computational chemistry applied to mechanistic and bonding riddles. 
fer conditions and unconventional cycloisomerization/dimerization of 1,6-enynes to form highly decorated tricyclic structures, or cross-coupling reactions. ${ }^{6}$

In order to provide wider applications to this family of all-metal aromatic clusters, we now turned our attention on trinuclear platinum clusters, whose solid-state structures evenly overlap with those of their palladium analogues. ${ }^{5 \mathrm{a}}$ In particular, the two clusters share nearly identical metal-metal, metal-sulfur, and metal-phosphine distances, differences remaining below $0.03 \AA$ at the solid states. Similarly, angles and dihedrals remain almost identical too, as witnessed by their perfectly equilateral trimetallic core. An ample mix of theoretical tools and experimental magnetic measures suggest perfect coincidence of delocalized bonding, which is responsible for the aromatic character of these complexes.

We speculated that this could have been of interest for activation of unsaturated substrates because mononuclear platinum salts have found large application in catalytic cycloisomerization reactions, with seminal contributions by Fürstner, ${ }^{7}$ Echavarren, ${ }^{8}$ and others. ${ }^{9}$ Surprisingly, while more than one hundred structures of trinuclear platinum clusters have been characterized at the solid state, none of them has been reported to trigger any $\mathrm{C}-\mathrm{C}$ bond-forming reaction. This led us to speculate whether aromatic $\mathrm{Pt}_{3}{ }^{+}$

Table 1 Optimization of Reaction Conditions ${ }^{\mathrm{a}}$

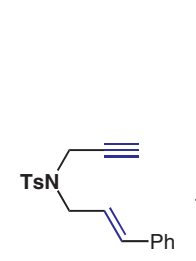

1a

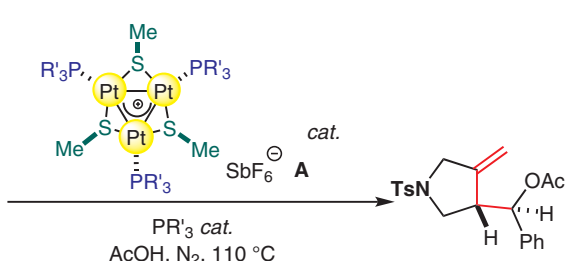

$\mathrm{AcOH}, \mathrm{N}_{2}, 110^{\circ} \mathrm{C}$

$\mathrm{R}^{\prime}=p$-Tol

\begin{tabular}{|c|c|c|c|c|c|}
\hline Entry & $\begin{array}{l}\text { Complex A } \\
\text { (mol\%) }\end{array}$ & Solvent & $\mathrm{PR}_{3}{ }_{3}$ (mol\%) & $\begin{array}{l}\text { Time } \\
\text { (h) }\end{array}$ & $\begin{array}{l}\text { Yield } \\
(\%)^{\mathrm{b}}\end{array}$ \\
\hline 1 & 0.3 & 1,4-dioxane & - & 16 & N.R. \\
\hline 2 & 0.3 & 1,2-DCE & - & 16 & N.R. \\
\hline 3 & 0.3 & toluene & - & 16 & 29 \\
\hline $4^{c}$ & 0.3 & toluene & - & 16 & N.R. \\
\hline $5^{d}$ & 0.3 & $\mathrm{AcOH}$ & - & 16 & 42 \\
\hline 6 & 0.3 & $\mathrm{AcOH}$ & 0.9 & 16 & 53 \\
\hline 7 & 0.3 & $\mathrm{AcOH}$ & 1.8 & 24 & 57 \\
\hline 8 & 0.3 & $\mathrm{AcOH}$ & 2.7 & 44 & 72 \\
\hline 9 & 0.6 & $\mathrm{AcOH}$ & 1.8 & 16 & 71 \\
\hline $10^{\mathrm{e}}$ & 0.6 & $\mathrm{AcOH}$ & 1.8 & 16 & 16 \\
\hline
\end{tabular}

a Reaction conditions: 1 a $(0.15 \mathrm{mmol}), \mathbf{A}(0.6 \mathrm{~mol} \%), \mathrm{AcOH}(0.15 \mathrm{mmol})$, solvent $(0.3 \mathrm{M})$, isolated yields.

${ }^{b}$ N. R.: No reaction.

c Reaction without $\mathrm{AcOH}$.

${ }^{d}$ Conditions: 1a (0.15 mmol), A (0.6 mol\%), AcOH (500 $\left.\mu \mathrm{L}, 0.3 \mathrm{M}\right)$

e Reaction with complex B (0.6 mol\%). complexes could hold potential for synthetic purposes instead, thus enabling a comparison with its widely-employed mononuclear peers.

In order to fill this lack and create a parallel to precedent contributions in the field of catalytic cycloisomerization of enynes, we focused on the reactivity of model substrate $(E)$ $\mathbf{1 a}$ in the presence of complex $\mathbf{A}$ (Table 1). Preliminary investigations on solvent effect, revealed the formation of pyrrolidine derivative $\mathbf{2 a}$ when using acetic acid, as an equimolar additive, in the presence of $0.3 \%$ of catalyst $\mathbf{A}$ in toluene (Table 1 , entries 1-3). A reaction conducted in the absence of the acidic additive (entry 4), reflected the importance of the former. Using AcOH as the solvent, compound 2a was isolated in $42 \%$ yield (entry 5 ). Encouraged by these results we continued the optimization of the reaction conditions fixing $\mathrm{AcOH}$ as the solvent for the cycloisomerization reaction. A strong effect was discovered by the addition of co-catalytic amounts of the phosphine ligand which, by ensuring a more stabilizing environment, led to the isolation of $\mathbf{2 a}$ in $72 \%$ yield although with prolonged reaction times (entries 6-8). Comparable efficacy was obtained increasing the catalyst loading to $0.6 \mathrm{~mol} \%$ in 16 hours (entry 9). Finally, the palladium analogue $\mathbf{B}$ was found to be less competent for the reaction, leading to $\mathbf{2 a}$ in a meagre $16 \%$ yield (entry 10).

The chemoselectivity of the catalyst is highly influenced by the nature of the carboxylic acid additive. Indeed, running the reaction in the presence of $(E)$-1a and equimolar amounts of benzoic acid in toluene, bicyclic product $\mathbf{2} \mathbf{a}^{\prime}$ was isolated as the major product in the reaction mixture (Scheme 2).
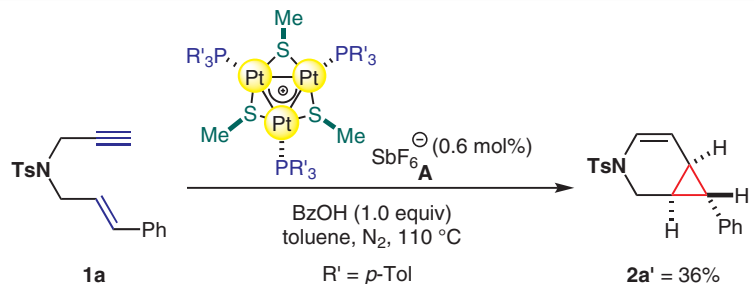

$2 a^{\prime}=36 \%$

Scheme 2 Acid-dependent cycloisomerizations of 1,6-enynes with trinuclear platinum complex

Subsequently, a family of differently substituted (E)-1,6enynes 1 were prepared in order to prove the generality of the methodology (Scheme 3). The tethering group ability was then investigated. Indeed, sulfonamide $\mathbf{1 b}$ and dialkyl malonyl units $\mathbf{1 c}, \mathbf{d}$ were efficiently converted in moderate to good yields, with these latter opening access to a family of cyclopentane derivatives. Next, we found several functional groups such as ether, fluoro, and trifluoro units on the cinnamyl moiety to be tolerated (Scheme 3, 2e-g). The aromatic phenyl ring could be replaced by naphthalene rings as well as different alkene derivatives such as dimethylallyl, crotyl, and the geranyl scaffold, providing the corre- 
sponding pyrrolidines $\mathbf{2 h}-\mathbf{k}$ in synthetically useful yields. Products 2a-c and 2e-k were obtained with high diastereocontrol $(d r>20: 1)$. Their relative configuration has been assigned on the basis of NOESY NMR correlation experiments, which revealed the anti-relationship between the two protons bonded to the contiguous stereogenic carbon atoms.

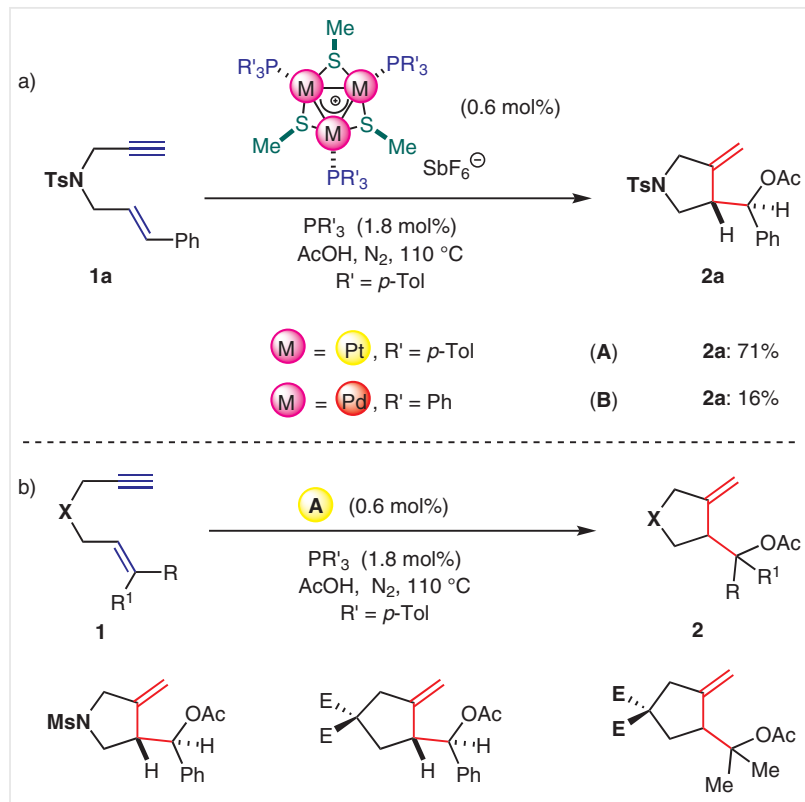

2b: $40 \%$

$\mathrm{E}=\mathrm{CO}_{2} \mathrm{Me}, 2 \mathrm{c}: 70 \%$

$\mathrm{E}=\mathrm{CO}_{2} \mathrm{Me}, \mathbf{2 d}: 56 \%$

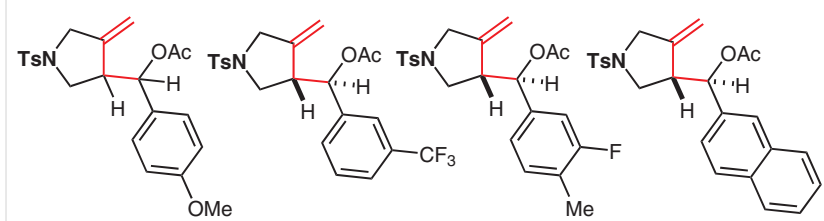

2e: $44 \%(d r 1: 1)$

$$
\text { 2f: } 36 \%
$$

2g: $41 \%$

2h: $43 \%$<smiles>C=C1CN([AlH2])CC1C(C)(C)OC(C)=O</smiles>

2i: $70 \%$

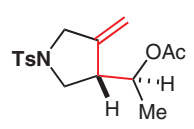

2j: $59 \%$

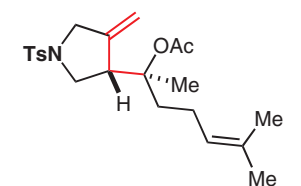

2k: $43 \%$
Scheme 3 Scope of the platinum-catalyzed reaction with (E)-enynes

At this point, we became interested in the reactivity of cis-1,6-enynes in cycloisomerization reactions catalyzed by all-aromatic clusters. To this end, 3a was synthesized and submitted to the previously optimized catalytic conditions. Surprisingly, platinum cluster A failed to promote any transformation. The reaction was then performed using just one equivalent of carboxylic acid and without any additional phosphine, which were the conditions adopted for the cycloisomerization of enynes with palladium cluster $\mathbf{B}^{6 a}$
We similarly observed no trace of conversion of 3a. However, use of this substrate in combination with palladium complex $\mathbf{B}$ led to the formation of bicyclic 1,4-diene scaffold 4a in good yields (Scheme 4a). ${ }^{10}$ Once again, the use of a mild carboxylic acid proved crucial for triggering any reactivity, no enyne conversion being otherwise observed. ${ }^{11}$

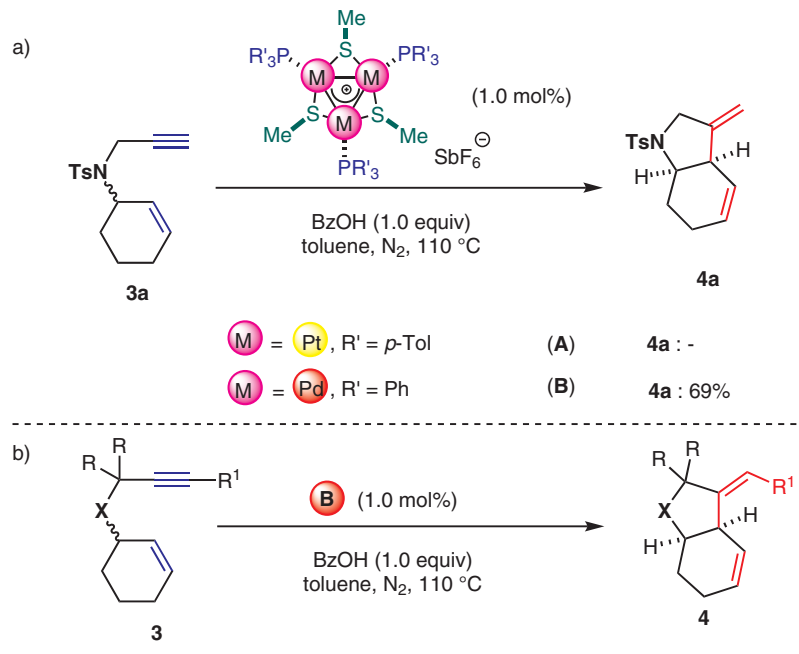

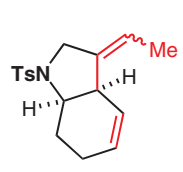

4b: $66 \%$

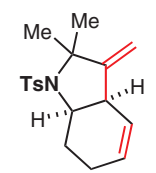

4c: $32 \%$

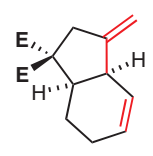

$\mathrm{E}=\mathrm{CO}_{2} \mathrm{Me}, \mathbf{4 d}: 70 \%$

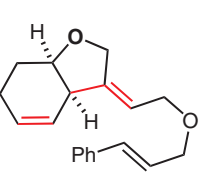

4e: $44 \%$
Scheme 4 Scope of the palladium-catalyzed reaction with (Z)-enynes

This synthetic application presented a quite wide generality and a family of bicyclic compounds was synthesized by employing different tethering units $\mathbf{4 b - e}$ (Scheme $4 \mathrm{~b}$ ). In contrast to observations made using 1,6-enynes with a trans-alkene arm, ${ }^{6 a}$ products 4 present a formal shift of the olefinic double bond and no traces of the corresponding 1,3-diene have been observed. In all cases, a high level of diastereoselection was observed ( $d r>20: 1)$, even though racemic substrates were used. The relative syn-configuration of bridgehead $\mathrm{CH}$ groups has been established through NMR correlation experiments. This structural feature parallel previous observations made on enantioenriched 1,6enynes using mononuclear palladium catalysts. ${ }^{12}$

We then performed some labeling experiments to get insights into the reaction mechanism. A reaction conducted with model substrate 1a in $\mathrm{AcOH}-d_{4}$, led to a highly unusual double incorporation of deuterium on the gem-methylene unit to form $[\mathrm{D}]_{2}-2 \mathrm{a}$ in good yield (57\%, Scheme 5 , top). In particular, D-labeling occurred with $90 \%$ and $63 \%$, respectively. 


\section{Sycthesis}

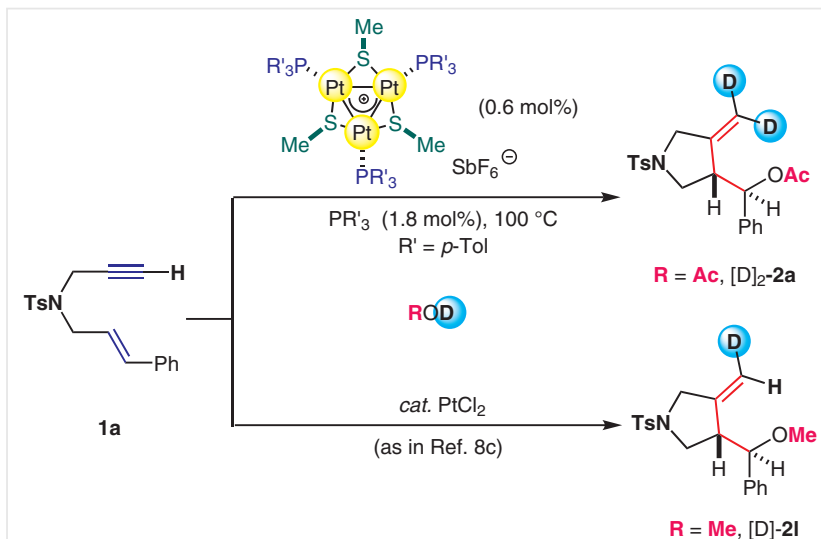

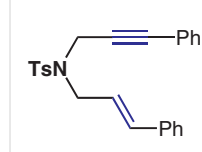

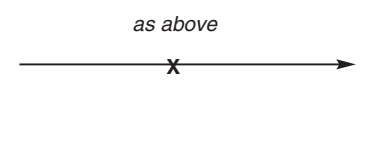

$1 \mathrm{~m}$

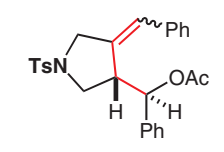

$2 \mathrm{~m}$
Scheme 5 Mechanistic probes

This result is in sharp contrast to previously findings in $\mathrm{PtCl}_{2}$-catalyzed alkoxycyclizations of enynes, in which a single deuterium atom was singularly incorporated under similar reaction conditions. ${ }^{8 \mathrm{C}}$ It is worth noting that no H/D exchange was observed by treating $1 \mathbf{a}$ with $\mathrm{AcOH}-d_{4}$. Internal alkyne derivative $\mathbf{1 m}$ was unreactive under standard reaction conditions (Scheme 5, bottom). These results show that the presence of a terminal alkyne group is crucial for triggering any reactivity with the trinuclear platinum complex and that their acetylenic $\mathrm{CH}$ is most likely activated during the catalytic cycle.

The reaction was finally followed by ${ }^{31} \mathrm{P}$ NMR spectroscopy. Interestingly, after four hours, decomposition of cluster $\mathbf{A}$ was observed along with the formation of new, not yet identified species. For the sake of comparison, complex $\mathbf{B}$ is on the contrary stable under similar conditions. ${ }^{6 a}$

These findings, taken together, are suggestive of a complimentary mood of action with respect to well established soft electrophilic $\pi$-activation by means of gold catalysis (Scheme 6). ${ }^{13}$ Particularly, in order to explain the deuterium labeling experiment, we propose an initial formation of platinum acetylide complex $\mathbf{C}$. Upon this $\sigma$-activation of the alkyne, a formal [2+2] cycloaddition forms key metalated cyclobutene $\mathbf{D}$, which further undergoes ring opening by the acetic acid. This generates vinylplatinum complex $\mathbf{E}$, in which the first H/D scrambling has already took place. Protodemetalation eventually delivers desired product $[D]_{2}-\mathbf{2 a}$. However, a dual $\sigma, \pi$-activation could not be excluded at this stage of the investigation. ${ }^{14}$ In this case, the electron-rich alkene arm of diplatinum complex $\mathbf{F}$ can attack the electrophilic alkyne carbon to yield carbocationic complex G. Subsequent formal quench by an acetate anion and dual proto- demetalation would then liberate product $[\mathrm{D}]_{2}-\mathbf{2 a}$. The absence of reactivity observed using substrates $\mathbf{3}$ could be consistent with the steric strain associated with the formation of the tricyclic intermediate corresponding to complex D. The loss of stereocontrol observed using substrate 1e, which has an electron-rich anisole fragment that can stabilize the benzylic carbocation of intermediate $\mathbf{G}$, might, however, be more in agreement with the second manifold instead.
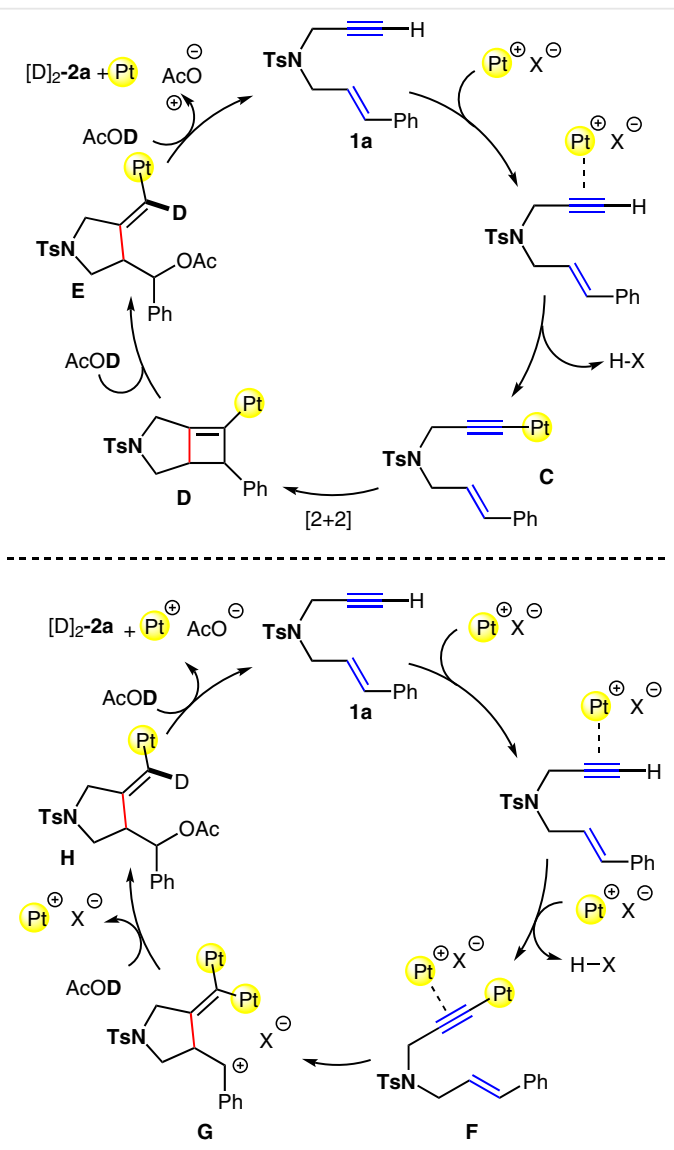

Scheme 6 Plausible catalytic cycles for the synthesis of $\left[D_{2}\right]-2 a$

In conclusion, we have reported on the unprecedented use of all-metal aromatic clusters in catalytic cycloisomerizations of 1,6-enyne derivatives. The proper choice of the catalyst allowed for the chemoselective synthesis of valuable classes of cyclic and bicyclic derivatives in good yields and functional group tolerance. Mechanistic hints allowed us to propose a new mode of activation for these clusters, which will be useful for further exploration of the possibilities of multinuclear complexes for catalytic synthesis.

Reactions were performed under standard Schlenk technique using commercial reagents used as received. Solvents were dried and stored over molecular sieves previously activated in an oven $\left(450^{\circ} \mathrm{C}\right.$ over- 
night). Catalytic reactions required the use of anhydrous solvents. Chromatographic purifications were performed under gradient using a Combiflash ${ }^{\circledR}$ system and prepacked disposable silica cartridges.

\section{Complex A}

$\mathrm{Pt}(\mathrm{dba})_{3}$ (90 mg, $0.1 \mathrm{mmol}, 1$ equiv) was added to a $50 \mathrm{~mL}$ Schlenk flask, which underwent at least three vacuum/ $\mathrm{N}_{2}$ cycles. $\mathrm{P}(p \text {-tol })_{3}(31$ $\mathrm{mg}, 0.1 \mathrm{mmol}, 1$ equiv) was added under $\mathrm{N}_{2}$. Then, freshly degassed $\mathrm{CHCl}_{3}(10 \mathrm{~mL})$ and dimethyl disulfide ( $9.5 \mathrm{mg}, 0.05 \mathrm{mmol}, 0.5$ equiv) were immediately syringed through the septum. The resulting solution was kept under stirring at r.t. for $2 \mathrm{~h}$ and $\mathrm{AgSbF}_{6}(12 \mathrm{mg}, 0.033$ mmol, 0.33 equiv) was then added under $\mathrm{N}_{2}$. The solution was kept in the dark. Stirring was maintained for $1 \mathrm{~h}$ and the mixture was then filtered under $\mathrm{N}_{2}$ through a short pad of Celite to remove traces of black metals. The solvent was removed under vacuum to leave a deep yellow-brown solid that was washed with a $\mathrm{CHCl}_{3} /$ hexane solution $(1: 30 \mathrm{v} / \mathrm{v}, 3 \times 20 \mathrm{~mL})$. Desired cluster was purified by chromatography on silica gel using acetone/hexane under gradient as eluent. Recrystallization by vapor diffusion using THF/hexane eventually provided the pure complex as yellow crystals; yield: $15 \mathrm{mg}$ (30\%). Their spectroscopic data correspond to the literature. ${ }^{5 a}$

\section{Complex B}

$\mathrm{Pd}(\mathrm{dba})_{2}$ (115 mg, $0.2 \mathrm{mmol}, 1$ equiv) was added to a $100 \mathrm{~mL}$ Schlenk flask, which underwent at least three vacuum $/ \mathrm{N}_{2}$ cycles. $\mathrm{PPh}_{3}(53 \mathrm{mg}$, $0.2 \mathrm{mmol}, 1$ equiv) was added under $\mathrm{N}_{2}$. Then, freshly degassed $\mathrm{CHCl}_{3}$ $(20 \mathrm{~mL})$ and dimethyl disulfide ( $19 \mathrm{mg}, 0.1 \mathrm{mmol}, 0.5$ equiv) were immediately syringed through the septum. The resulting solution was kept under stirring at r.t. for $2 \mathrm{~h}$ and $\mathrm{AgSbF}_{6}(12 \mathrm{mg}, 0.033 \mathrm{mmol}, 0.33$ equiv) was then added under $\mathrm{N}_{2}$. The solution was kept in the dark. Stirring was maintained for $1 \mathrm{~h}$ and the mixture was then filtered under $\mathrm{N}_{2}$ through a short pad of Celite to remove traces of black metals. The solvent was removed under vacuum to leave a deep red solid that was washed with a $\mathrm{CHCl}_{3} /$ hexane solution $(1: 30 \mathrm{v} / \mathrm{v}, 3 \times 30 \mathrm{~mL})$. Desired cluster was directly purified by recrystallization via vapor diffusion using acetone/hexane, eventually providing the pure complex as red crystals; yield: $88 \mathrm{mg}$ (97\%). Their spectroscopic data correspond to the literature. ${ }^{5 a}$

\section{Catalytic Synthesis of 2; General Procedure 1 (GP-1)}

Complex A (1.7 mg, $0.9 \mathrm{mmol}, 0.6 \mathrm{~mol} \%$ ) and freshly degassed $\mathrm{AcOH}$ $(0.5 \mathrm{~mL})$ were added under $\mathrm{N}_{2}$ to a Schlenk-type flask. The desired substrate 1 ( $0.15 \mathrm{mmol}, 1$ equiv) and $\mathrm{P}(p \text {-tolyl })_{3}(0.8 \mathrm{mg}, 2.7 \mathrm{mmol}$, $1.8 \mathrm{~mol} \%$ ) were sequentially added. The mixture was heated at $110{ }^{\circ} \mathrm{C}$ and the conversion was followed by analyzing samples via TLC. Upon complete conversion of the substrate, the solution was diluted with EtOAc $(5 \mathrm{~mL})$ and purified.

\section{Catalytic Synthesis of 4; General Procedure 2 (GP-2)}

Complex B (3 mg, $0.002 \mathrm{mmol}, 1 \mathrm{~mol} \%$ ) and freshly degassed toluene (3.5 mL) were added under $\mathrm{N}_{2}$ to a Schlenk-type flask. The desired substrate 3 ( $0.2 \mathrm{mmol}, 0.06 \mathrm{M}$ ) and benzoic acid ( $24.5 \mathrm{mg}, 0.2 \mathrm{mmol}$, 1 equiv) were sequentially added. The mixture was heated at $100{ }^{\circ} \mathrm{C}$ and the conversion was followed by analyzing samples via TLC. Upon complete conversion of the substrate, the solution was diluted with EtOAc ( $5 \mathrm{~mL})$ and purified.

\section{(4-Methylene-1-tosylpyrrolidin-3-yl)(phenyl)methyl Acetate (2a)} Product 2a was isolated following GP-1 as a pale yellow oil (71\%, 42 mg, $0.105 \mathrm{mmol}$ ) using $\mathbf{1 a}(50 \mathrm{mg}, 0.15 \mathrm{mmol})$ as reagent. Spectra correspond to the literature. ${ }^{15}$
${ }^{1} \mathrm{H}$ NMR $\left(300 \mathrm{MHz}, \mathrm{CDCl}_{3}\right): \delta=7.71(\mathrm{~d}, J=8.2 \mathrm{~Hz}, 2 \mathrm{H}), 7.37-7.25(\mathrm{~m}, 7$ H), $5.71(\mathrm{~d}, J=7.1 \mathrm{~Hz}, 1 \mathrm{H}), 4.92(\mathrm{~d}, J=2.0 \mathrm{~Hz}, 1 \mathrm{H}), 4.53(\mathrm{~d}, J=2.1 \mathrm{~Hz}$, $1 \mathrm{H}), 3.87-3.73(\mathrm{~m}, 2 \mathrm{H}), 3.43-3.33(\mathrm{~m}, 2 \mathrm{H}), 3.18-3.12(\mathrm{~m}, 1 \mathrm{H}), 2.46$ (s, $3 \mathrm{H}), 2.01(\mathrm{~s}, 3 \mathrm{H})$.

[4-(Methylene- $\left.d_{2}\right)$-1-tosylpyrrolidin-3-yl](phenyl)methyl Acetate$d_{3}\left([D]_{2}-2 a\right)$

Product $[\mathrm{D}]_{2}-\mathbf{2 a}$ was isolated following $\mathbf{G P - 1}$ as a pale yellow oil (57\%, $33 \mathrm{mg}, 0.086 \mathrm{mmol}$ ) using $\mathbf{1 a}(50 \mathrm{mg}, 0.15 \mathrm{mmol})$ and $\mathrm{AcOH}-\mathrm{d}_{4}$ as solvent.

IR (neat): 3032, 2921, 1740, 1344, 1158, 1042, $583 \mathrm{~cm}^{-1}$.

${ }^{1} \mathrm{H} \mathrm{NMR}\left(300 \mathrm{MHz}, \mathrm{CDCl}_{3}\right): \delta=7.71(\mathrm{~d}, J=8.2 \mathrm{~Hz}, 2 \mathrm{H}), 7.37-7.23(\mathrm{~m}, 7$ H), $5.72(\mathrm{~d}, J=7.1 \mathrm{~Hz}, 1 \mathrm{H}), 4.90(\mathrm{~d}, J=2.0 \mathrm{~Hz}, 0.1 \mathrm{H}), 4.52(\mathrm{~d}, J=2.1 \mathrm{~Hz}$, $0.37 \mathrm{H}), 3.86-3.74(\mathrm{~m}, 2 \mathrm{H}), 3.43-3.34(\mathrm{~m}, 2 \mathrm{H}), 3.18-3.13(\mathrm{~m}, 1 \mathrm{H})$, $2.46(\mathrm{~s}, 3 \mathrm{H})$.

${ }^{13} \mathrm{C}$ NMR $\left(101 \mathrm{MHz}, \mathrm{CDCl}_{3}\right): \delta=169.7,143.8,142.7,138.4,132.7$, 129.7, 128.5, 128.3, 127.8, 126.8, 109.9, 75.3, 52.5, 49.9, 48.1, 45.5, 21.6.

LC-MS: $m / z$ calcd for $\mathrm{C}_{21} \mathrm{H}_{18} \mathrm{NO}_{4} \mathrm{SNa}[\mathrm{M}+\mathrm{Na}]^{+}:$413.1; found: 413.3 .

\section{[4-Methylene-1-(methylsulfonyl)pyrrolidin-3-yl](phenyl)methyl} Acetate (2b)

Product 2b was isolated following GP-1 as a colorless oil (40\%, 18.5 $\mathrm{mg}, 0.06 \mathrm{mmol}$ ) using $\mathbf{1 b}(37 \mathrm{mg}, 0.15 \mathrm{mmol})$ as reagent.

IR (neat): 2926, 1740, 1328, 1225, 1148, 1049, 959, $699 \mathrm{~cm}^{-1}$.

${ }^{1} \mathrm{H}$ NMR $\left(400 \mathrm{MHz}, \mathrm{CDCl}_{3}\right): \delta=7.35-7.29(\mathrm{~m}, 5 \mathrm{H}), 5.87(\mathrm{~d}, J=6.9 \mathrm{~Hz}, 1$ H), $5.02(\mathrm{~s}, 1 \mathrm{H}), 4.68(\mathrm{~s}, 1 \mathrm{H}), 4.01-3.88(\mathrm{~m}, 2 \mathrm{H}), 3.55-3.44(\mathrm{~m}, 2 \mathrm{H})$, 3.31-3.25 (m, $1 \mathrm{H}), 2.82(\mathrm{~s}, 3 \mathrm{H}), 2.09(\mathrm{~s}, 3 \mathrm{H})$.

${ }^{13} \mathrm{C}$ NMR $\left(101 \mathrm{MHz}, \mathrm{CDCl}_{3}\right): \delta=169.9,142.8,138.2,128.6,128.5$, $126.8,110.6,75.0,52.3,49.7,48.7,35.3,21.1$

LC-MS: $m / z$ calcd for $\mathrm{C}_{15} \mathrm{H}_{19} \mathrm{NO}_{4} \mathrm{SNa}[\mathrm{M}+\mathrm{Na}]^{+}$: 332.093; found: 332.217 .

\section{Dimethyl 3-[Acetoxy(phenyl)methyl]-4-methylenecyclopentane- 1,1-dicarboxylate (2c)}

Product 2c was isolated following GP-1 as a pale yellow oil (70\%, 36 $\mathrm{mg}, 0.105 \mathrm{mmol}$ ) using $1 \mathrm{c}$ (42 $\mathrm{mg}, 0.15 \mathrm{mmol})$ as reagent.

IR (neat): 2952, 2362, 1730, 1372, 1226, 1022, 895, $699 \mathrm{~cm}^{-1}$.

${ }^{1} \mathrm{H}$ NMR (300 MHz, $\left.\mathrm{CDCl}_{3}\right): \delta=7.35-7.25(\mathrm{~m}, 5 \mathrm{H}), 5.91(\mathrm{~d}, J=5.8 \mathrm{~Hz}, 1$ $\mathrm{H}), 4.98(\mathrm{~d}, J=2.2 \mathrm{~Hz}, 1 \mathrm{H}), 4.64(\mathrm{~d}, J=2.2 \mathrm{~Hz}, 1 \mathrm{H}), 3.73(\mathrm{~s}, 3 \mathrm{H}), 3.69$ (s, $3 \mathrm{H}), 3.17-3.09(\mathrm{~m}, 1 \mathrm{H}), 2.94(\mathrm{~s}, 2 \mathrm{H}), 2.48-2.41(\mathrm{~m}, 1 \mathrm{H}), 2.23-$ $2.15(\mathrm{~m}, 1 \mathrm{H}), 2.07(\mathrm{~s}, 3 \mathrm{H})$.

${ }^{13} \mathrm{C}$ NMR $\left(75 \mathrm{MHz}, \mathrm{CDCl}_{3}\right): \delta=171.9,171.7,170.1,146.9,139.2,128.4$, 127.9, 126.6, 109.4, 76.3, 58.3, 52.8, 52.7, 47.6, 41.8, 35.4, 21.0.

LC-MS: $m / z$ calcd for $\mathrm{C}_{19} \mathrm{H}_{22} \mathrm{O}_{6} \mathrm{Na}[\mathrm{M}+\mathrm{Na}]^{+}:$369.1; found: 369.2 .

\section{Dimethyl 3-(2-Acetoxypropan-2-yl)-4-methylenecyclopentane- 1,1-dicarboxylate (2d)}

Product 2d was isolated following GP-1 as a colorless oil (56\%, $25 \mathrm{mg}$, $0.084 \mathrm{mmol}$ ) using $\mathbf{1 d}(42 \mathrm{mg}, 0.15 \mathrm{mmol}$ ) as reagent.

IR (neat): 2953, 1729, 1367, 1230, 1076, 1018, 896, $610 \mathrm{~cm}^{-1}$.

${ }^{1} \mathrm{H} \mathrm{NMR}\left(300 \mathrm{MHz}, \mathrm{CDCl}_{3}\right): \delta=5.07(\mathrm{~s}, 1 \mathrm{H}), 4.96(\mathrm{~s}, 1 \mathrm{H}), 3.73(\mathrm{~s}, 3 \mathrm{H})$, $3.71(\mathrm{~s}, 3 \mathrm{H}), 3.17-3.11(\mathrm{~m}, 1 \mathrm{H}), 2.88(\mathrm{~s}, 2 \mathrm{H}), 2.64-2.56(\mathrm{~m}, 1 \mathrm{H})$, 2.04-1.99 (m, $1 \mathrm{H}), 1.96$ (s, $3 \mathrm{H}), 1.49$ (s, $3 \mathrm{H}), 1.45$ (s, $3 \mathrm{H})$.

${ }^{13} \mathrm{C}$ NMR $\left(75 \mathrm{MHz}, \mathrm{CDCl}_{3}\right): \delta=171.8,171.7,170.3,147.5,111.2,84$, $58.5,52.8,50.3,43.6,35.7,23.6,22.8,22.4$. 
LC-MS: $m / z$ calcd for $\mathrm{C}_{15} \mathrm{H}_{22} \mathrm{O}_{6} \mathrm{Na}[\mathrm{M}+\mathrm{Na}]^{+}$: 321.1; found: 321.2 .

\section{(4-Methoxyphenyl)(4-methylene-1-tosylpyrrolidin-3-yl)methyl Acetate (2e)}

Product 2e was isolated following GP-1 as a colorless oil (44\%, $27 \mathrm{mg}$, $0.066 \mathrm{mmol}, \mathrm{dr}$ 6:4) using $1 \mathrm{e}(53 \mathrm{mg}, 0.15 \mathrm{mmol})$ as reagent.

IR (neat): 2922, 1737, 1513, 1344, 1227, 1159, 1027, $661 \mathrm{~cm}^{-1}$.

${ }^{1} \mathrm{H} \mathrm{NMR}\left(400 \mathrm{MHz}, \mathrm{CDCl}_{3}\right): \delta=7.69(\mathrm{~d}, J=8.3 \mathrm{~Hz}, 2 \mathrm{H}), 7.63(\mathrm{~d}, J=8.3$ $\mathrm{Hz}, 2 \mathrm{H}), 7.33(\mathrm{t}, J=7.9 \mathrm{~Hz}, 4 \mathrm{H}), 7.16(\mathrm{~d}, J=7.9 \mathrm{~Hz}, 4 \mathrm{H}), 6.85-6.82(\mathrm{~m}$, $4 \mathrm{H}), 5.62-5.56(\mathrm{~m}, 2 \mathrm{H}), 5.04(\mathrm{~d}, J=18.2 \mathrm{~Hz}, 2 \mathrm{H}), 4.87(\mathrm{~d}, J=2.0 \mathrm{~Hz}, 1$ $\mathrm{H}), 4.47(\mathrm{~d}, J=2.1 \mathrm{~Hz}, 1 \mathrm{H}), 3.88-3.69(\mathrm{~m}, 4 \mathrm{H}), 3.80(\mathrm{~s}, 3 \mathrm{H}), 3.78(\mathrm{~s}, 3$ H), 3.44-3.40 (m, $1 \mathrm{H}), 3.33-3.29(\mathrm{~m}, 1 \mathrm{H}), 3.16-2.96(\mathrm{~m}, 4 \mathrm{H}), 2.44(\mathrm{~s}$, $3 \mathrm{H}), 1.99(\mathrm{~s}, 3 \mathrm{H}), 1.98(\mathrm{~s}, 3 \mathrm{H})$.

${ }^{13} \mathrm{C}$ NMR (101 MHz, $\mathrm{CDCl}_{3}$ ): $\delta=169.8$ (da), $169.7(d \mathrm{~b}), 159.7$ (da), 159.5 (db), 144.2, 143.8 (da), $143.8(d \mathrm{~b}), 142.9,132.8(d a), 132.7(d \mathrm{~b})$, 130.5 (da), $130.0(d \mathrm{~b}), 129.7(d \mathrm{a}), 129.7(d \mathrm{~b}), 128.7(d \mathrm{a}), 128.3(d \mathrm{~b})$, 127.8, $114.0(d a), 113.8(d b), 110.6(d a), 110.3(d b), 75.3(d a), 75.3$ (db), $55.3(d a), 55.3(d b), 52.5(d a), 52.1(d b), 50.2(d a), 50.0(d b), 48.3$ (da), $48.0(d \mathrm{~b}), 21.6,21.1(d \mathrm{a}), 21.0(d \mathrm{~b})$.

LC-MS: $m / z$ calcd for $\mathrm{C}_{22} \mathrm{H}_{25} \mathrm{NO}_{5} \mathrm{SNa}[\mathrm{M}+\mathrm{Na}]^{+}$: 438.1; found: 438.3 .

\section{(4-Methylene-1-tosylpyrrolidin-3-yl)[3-(trifluoromethyl)phe- nyl]methyl Acetate (2f)}

Product 2f was isolated following GP-1 as a colorless oil (36\%, $20 \mathrm{mg}$, $0.044 \mathrm{mmol}$ ) using $\mathbf{1 f}(59 \mathrm{mg}, 0.15 \mathrm{mmol}$ ) as reagent.

IR (neat): 2979, 1751, 1329, 1226, 1163, 903, 722, $650 \mathrm{~cm}^{-1}$.

${ }^{1} \mathrm{H}$ NMR $\left(400 \mathrm{MHz}, \mathrm{CDCl}_{3}\right): \delta=7.69(\mathrm{~d}, J=8.2 \mathrm{~Hz}, 2 \mathrm{H}), 7.47-7.33(\mathrm{~m}, 6$ H), $5.70(\mathrm{~d}, J=7.3 \mathrm{~Hz}, 1 \mathrm{H}), 4.92(\mathrm{~d}, J=1.7 \mathrm{~Hz}, 1 \mathrm{H}), 4.46(\mathrm{~d}, J=1.7 \mathrm{~Hz}$, $1 \mathrm{H}), 3.78(\mathrm{~s}, J=6.2 \mathrm{~Hz}, 2 \mathrm{H}), 3.41-3.30(\mathrm{~m}, 2 \mathrm{H}), 3.12-3.08(\mathrm{~m}, 1 \mathrm{H})$, $2.44(\mathrm{~s}, 3 \mathrm{H}), 2.02(\mathrm{~s}, 3 \mathrm{H})$.

${ }^{13} \mathrm{C}$ NMR $\left(101 \mathrm{MHz}, \mathrm{CDCl}_{3}\right): \delta=169.6,144.0,142.5,139.5,130.4$, $129.8,129.0,127.8,127.2,126.4,125.2\left(\mathrm{q},{ }^{2} J_{C, F}=3.7 \mathrm{~Hz}\right), 123.5\left(\mathrm{q},{ }^{3} J_{\mathrm{C}, \mathrm{F}}\right.$ $=3.7 \mathrm{~Hz}), 123.0\left(\mathrm{~d},{ }^{1} J_{\mathrm{C}, \mathrm{F}}=273 \mathrm{~Hz}\right), 110.8,74.7,52.3,49.8,48.3,21.5$, 20.9 .

${ }^{19} \mathrm{~F}$ NMR (376 MHz, $\mathrm{CDCl}_{3}$ ): $\delta=-62.7$.

LC-MS: $m / z$ calcd for $\mathrm{C}_{22} \mathrm{H}_{22} \mathrm{~F}_{3} \mathrm{NO}_{4} \mathrm{SNa}[\mathrm{M}+\mathrm{Na}]^{+}$: 476.1; found: 476.1 .

\section{(3-Fluoro-4-methylphenyl)(4-methylene-1-tosylpyrrolidin-3- yl)methyl Acetate (2g)}

Product $\mathbf{2 g}$ was isolated following GP-1 as a colorless oil $(41 \%, 25 \mathrm{mg}$, $0.062 \mathrm{mmol}$ ) using $1 \mathrm{~g}$ (52 $\mathrm{mg}, 0.15 \mathrm{mmol}$ ) as reagent.

IR (neat): 2926, 1740, 1371, 1344, 1223, 1160, 662, $588 \mathrm{~cm}^{-1}$.

${ }^{1} \mathrm{H}$ NMR $\left(400 \mathrm{MHz}, \mathrm{CDCl}_{3}\right.$ ): $\delta=7.69(\mathrm{~d}, J=8.3 \mathrm{~Hz}, 2 \mathrm{H}), 7.33(\mathrm{~d}, J=8.4$ $\mathrm{Hz}, 2 \mathrm{H}), 7.11(\mathrm{t}, J=7.8 \mathrm{~Hz}, 1 \mathrm{H}), 6.90-6.84(\mathrm{~m}, 2 \mathrm{H}), 5.62(\mathrm{~d}, J=7.1 \mathrm{~Hz}$, $1 \mathrm{H}), 4.91(\mathrm{~s}, 1 \mathrm{H}), 4.54(\mathrm{~s}, 1 \mathrm{H}), 3.84-3.71(\mathrm{~m}, 2 \mathrm{H}), 3.39-3.30(\mathrm{~m}, 2 \mathrm{H})$, 3.10-3.06 (m, $1 \mathrm{H}), 2.44$ (s, $3 \mathrm{H}), 2.23$ (s, $3 \mathrm{H}), 1.99$ (s, $3 \mathrm{H})$.

${ }^{13} \mathrm{C}$ NMR $\left(101 \mathrm{MHz}, \mathrm{CDCl}_{3}\right): \delta=169.6,161.1\left(\mathrm{~d},{ }^{1} J_{\mathrm{C}, \mathrm{F}}=245 \mathrm{~Hz}\right), 143.9$, 142.7, 138.1, 132.7, $131.5\left(\mathrm{~d},{ }^{4} J_{\mathrm{C}, \mathrm{F}}=5.3 \mathrm{~Hz}\right), 129.7,127.8,124.9(\mathrm{~d}$, $\left.{ }^{3} J_{C, F}=17 \mathrm{~Hz}\right), 122.3\left(\mathrm{~d}, J_{\mathrm{C}, \mathrm{F}}=3 \mathrm{~Hz}\right), 113.3\left(\mathrm{~d},{ }^{2} J_{\mathrm{C}, \mathrm{F}}=23 \mathrm{~Hz}\right), 110.4,74.6$, 52.4, 49.8, 48.1, 21.6, 20.9, $14.3\left(\mathrm{~d},{ }^{6} J_{\mathrm{C}, \mathrm{F}}=3 \mathrm{~Hz}\right)$.

${ }^{19} \mathrm{~F}$ NMR (376 MHz, $\mathrm{CDCl}_{3}$ ): $\delta=-116$.

LC-MS: $m / z$ calcd for $\mathrm{C}_{22} \mathrm{H}_{24} \mathrm{FNO}_{4} \mathrm{SNa}[\mathrm{M}+\mathrm{Na}]^{+}$: 440.1 ; found: 440.2 .

\section{(4-Methylene-1-tosylpyrrolidin-3-yl)(naphthalen-2-yl)methyl} Acetate (2h)

Product 2h was isolated following GP-1 as a colorless oil (43\%, $28 \mathrm{mg}$, $0.065 \mathrm{mmol}$ ) using $\mathbf{1 h}$ (56 $\mathrm{mg}, 0.15 \mathrm{mmol}$ ) as reagent.
IR (neat): 2924, 1737, 1344, 1223, 1160, 1093, 814, $547 \mathrm{~cm}^{-1}$. ${ }^{1} \mathrm{H}$ NMR $\left(400 \mathrm{MHz}, \mathrm{CDCl}_{3}\right): \delta=7.82-7.80(\mathrm{~m}, 3 \mathrm{H}), 7.70-7.68(\mathrm{~m}, 3 \mathrm{H})$, 7.50-7.48 (m, $2 \mathrm{H}), 7.36-7.31(\mathrm{~m}, 3 \mathrm{H}), 5.86(\mathrm{~d}, J=7.2 \mathrm{~Hz}, 1 \mathrm{H}), 4.88(\mathrm{~s}$, $1 \mathrm{H}), 4.51$ (s, $1 \mathrm{H}), 3.86-3.77$ (m, $2 \mathrm{H}), 3.42-3.41$ (m, $2 \mathrm{H}), 3.28-3.21$ ( $\mathrm{m}, 1 \mathrm{H}), 2.44(\mathrm{~s}, 3 \mathrm{H}), 2.03(\mathrm{~s}, 3 \mathrm{H})$.

${ }^{13} \mathrm{C}$ NMR $\left(101 \mathrm{MHz}, \mathrm{CDCl}_{3}\right): \delta=169.7,143.8,142.9,135.7,133.2$, $132.9,132.8,127.9,128.4,128.1,127.9,127.7,126.4,126.4,126.3$, $124.3,110.4,75.6,52.5,50.0,48.0,21.6,21.0$.

LC-MS: $m / z$ calcd for $\mathrm{C}_{25} \mathrm{H}_{25} \mathrm{NO}_{4} \mathrm{SNa}[\mathrm{M}+\mathrm{Na}]^{+}$: 458.1; found: 458.3 .

2-(4-Methylene-1-tosylpyrrolidin-3-yl)propan-2-yl Acetate (2i)

Product $\mathbf{2 i}$ was isolated following GP-1 as a pale yellow oil (70\%, 35 $\mathrm{mg}, 0.105 \mathrm{mmol}$ ) using $1 \mathbf{i}(41 \mathrm{mg}, 0.15 \mathrm{mmol}$ ) as reagent. Spectra correspond to the literature. ${ }^{16}$

${ }^{1} \mathrm{H}$ NMR $\left(300 \mathrm{MHz}, \mathrm{CDCl}_{3}\right): \delta=7.68(\mathrm{~d}, J=8.2 \mathrm{~Hz}, 2 \mathrm{H}), 7.34(\mathrm{~d}, J=8.0$ $\mathrm{Hz}, 2 \mathrm{H}), 5.04(\mathrm{~d}, J=10.6 \mathrm{~Hz}, 1 \mathrm{H}), 3.86(\mathrm{~d}, J=12.1 \mathrm{~Hz}, 1 \mathrm{H}), 3.71(\mathrm{~d}, J=$ $13.7 \mathrm{~Hz}, 1 \mathrm{H}), 3.71(\mathrm{~d}, J=13.7 \mathrm{~Hz}, 1 \mathrm{H}), 3.41(\mathrm{dd}, J=9.6,3.1 \mathrm{~Hz}, 1 \mathrm{H})$, 3.33-3.31 (m, $1 \mathrm{H}), 3.25-3.19$ (m, $1 \mathrm{H}), 2.42(\mathrm{~s}, 3 \mathrm{H}), 1.91(\mathrm{~s}, 3 \mathrm{H}), 1.45$ (s, $3 \mathrm{H}), 1.46(\mathrm{~s}, 3 \mathrm{H})$.

\section{1-(4-Methylene-1-tosylpyrrolidin-3-yl)ethyl Acetate (2j)}

Product $\mathbf{2 j}$ was isolated following $\mathbf{~ G P - 1}$ as a colorless oil $(59 \%, 28 \mathrm{mg}$, $0.087 \mathrm{mmol}$ ) using $\mathbf{1 j}$ ( $35 \mathrm{mg}, 0.15 \mathrm{mmol}$ ) as reagent.

IR (neat): 2926, 1734, 1372, 1343, 1159, 1092, 662, $547 \mathrm{~cm}^{-1}$.

${ }^{1} \mathrm{H}$ NMR $\left(400 \mathrm{MHz}, \mathrm{CDCl}_{3}\right): \delta=7.71(\mathrm{~d}, J=8.2 \mathrm{~Hz}, 2 \mathrm{H}), 7.34(\mathrm{~d}, J=8.0$ $\mathrm{Hz}, 2 \mathrm{H}$ ), 5.01 (dd, $J=18.6,2.0 \mathrm{~Hz}, 2 \mathrm{H}$ ), 4.96-4.93 (m, $1 \mathrm{H}$ ), 3.85-3.72 (m, $2 \mathrm{H}), 3.43(\mathrm{dd}, J=9.8,7.9 \mathrm{~Hz}, 1 \mathrm{H}), 3.27-3.23(\mathrm{~m}, 1 \mathrm{H}), 2.82-2.79$ (m, $1 \mathrm{H}), 2.43(\mathrm{~s}, 3 \mathrm{H}), 1.92(\mathrm{~s}, 3 \mathrm{H}), 1.18(\mathrm{dd}, J=10.2,5.9 \mathrm{~Hz}, 3 \mathrm{H})$.

${ }^{13} \mathrm{C}$ NMR $\left(101 \mathrm{MHz}, \mathrm{CDCl}_{3}\right): \delta=170.1,143.8,143.8,132.8,129.7$, $127.8,109.4,70.1,52.5,49.3,47.5,21.5,21.0,17.8$.

LC-MS: $m / z$ calcd for $\mathrm{C}_{16} \mathrm{H}_{21} \mathrm{NO}_{4} \mathrm{SNa}[\mathrm{M}+\mathrm{Na}]^{+}: 346.1$; found: 346.2 .

\section{6-Methyl-2-(4-methylene-1-tosylpyrrolidin-3-yl)hept-5-en-2-yl Acetate (2k)}

Product 2k was isolated following GP-1 as a pale yellow oil (43\%, 26 $\mathrm{mg}, 0.065 \mathrm{mmol}$ ) using $1 \mathbf{k}(35 \mathrm{mg}, 0.15 \mathrm{mmol}$ ) as reagent.

IR (neat): 2923, 1734, 1345, 1237, 1160, 1094, 660, $589 \mathrm{~cm}^{-1}$.

${ }^{1} \mathrm{H}$ NMR $\left(300 \mathrm{MHz}, \mathrm{CDCl}_{3}\right): \delta=7.70(\mathrm{~d}, J=8.3 \mathrm{~Hz}, 2 \mathrm{H}), 7.33(\mathrm{~d}, J=7.9$ $\mathrm{Hz}, 2 \mathrm{H}), 5.05-4.98(\mathrm{~m}, 2 \mathrm{H}), 3.92-3.67(\mathrm{~m}, 2 \mathrm{H}), 3.54-3.48(\mathrm{~m}, 2 \mathrm{H})$, 3.23-3.17 (m, $2 \mathrm{H}), 2.43(\mathrm{~s}, 3 \mathrm{H}), 2.06-2.89(\mathrm{~m}, 2 \mathrm{H}), 1.96(\mathrm{~s}, 3 \mathrm{H})$, 1.81-1.72 (m, $1 \mathrm{H}), 1.66(\mathrm{~s}, 3 \mathrm{H}), 1.67(\mathrm{~s}, 3 \mathrm{H}), 1.46-1.38(\mathrm{~m}, 1 \mathrm{H}), 1.31$ (s, $3 \mathrm{H})$.

${ }^{13} \mathrm{C} \mathrm{NMR}\left(75 \mathrm{MHz}, \mathrm{CDCl}_{3}\right): \delta=170.2,143.7,132.5,132.0,129.7,127.8$, $127.2,123.4,111.5,85.4,53.2,49.6,49.1,35.3,25.7,22.2,22.0,21.5$, 20.6, 17.6.

HRMS: $m / z$ calcd for $\mathrm{C}_{22} \mathrm{H}_{31} \mathrm{NO}_{4} \mathrm{SNa}[\mathrm{M}+\mathrm{Na}]^{+}$: 428.1875; found: 428.1869 .

\section{(3a,7a)-3-Methylene-1-tosyl-2,3,3a,6,7,7a-hexahydro-1H-indole (4a)}

Product 4a was isolated following GP-2 as a colorless oil (69\%, 60.1 $\mathrm{mg}, 0.21 \mathrm{mmol})$ using $3 \mathbf{a}(87 \mathrm{mg}, 0.3 \mathrm{mmol})$ as reagent. Spectroscopic data correspond to the literature. ${ }^{15}$

${ }^{1} \mathrm{H}$ NMR $\left(300 \mathrm{MHz}, \mathrm{CDCl}_{3}\right): \delta=7.73(\mathrm{~d}, J=8.3 \mathrm{~Hz}, 2 \mathrm{H}), 7.30(\mathrm{~d}, J=8.0$ $\mathrm{Hz}, 2 \mathrm{H}), 5.80-5.77(\mathrm{~m}, 1 \mathrm{H}), 5.65-5.60(\mathrm{~m}, 1 \mathrm{H}), 4.98(\mathrm{~d}, J=2.2 \mathrm{~Hz}, 1$ $\mathrm{H}), 4.84(\mathrm{~d}, J=2.3 \mathrm{~Hz}, 1 \mathrm{H}), 4.01-3.84(\mathrm{~m}, 3 \mathrm{H}), 2.73(\mathrm{br} \mathrm{s}, 1 \mathrm{H}), 2.42(\mathrm{~s}$, $3 \mathrm{H}), 2.11-1.89(\mathrm{~m}, 3 \mathrm{H}), 1.63-1.51(\mathrm{~m}, 1 \mathrm{H})$. 
The syn-configuration was determinated by NOESY NMR experiment.

\section{3-Ethylidene-1-tosyl-2,3,3a,6,7,7a-hexahydro-1H-indole (4b)}

Product $\mathbf{4 b}$ was isolated following GP-2 as a colorless oil (66\%, $60 \mathrm{mg}$, $0.2 \mathrm{mmol}$ ) using $\mathbf{3 b}$ (91 $\mathrm{mg}, 0.3 \mathrm{mmol})$ as reagent.

IR (neat): 2922, 1597, 1333, 1157, 1092, 814, 663, $545 \mathrm{~cm}^{-1}$.

${ }^{1} \mathrm{H}$ NMR $\left(400 \mathrm{MHz}, \mathrm{CDCl}_{3}\right): \delta=7.73(\mathrm{~d}, J=8.3 \mathrm{~Hz}, 2 \mathrm{H}), 7.30(\mathrm{~d}, J=8.1$ $\mathrm{Hz}, 2 \mathrm{H}), 5.77-5.75(\mathrm{~m}, 1 \mathrm{H}), 5.62-5.57(\mathrm{~m}, 1 \mathrm{H}), 5.24-5.17(\mathrm{~m}, 1 \mathrm{H})$, 4.07-4.01 (m, $1 \mathrm{H}), 3.86-3.79(\mathrm{~m}, 1 \mathrm{H}), 2.71$ (br s, $1 \mathrm{H}), 2.42$ (s, $3 \mathrm{H}$ ), 2.20-1.86 (m, $4 \mathrm{H}), 1.64-1.55(\mathrm{~m}, 4 \mathrm{H})$.

${ }^{13} \mathrm{C}$ NMR $\left(101 \mathrm{MHz}, \mathrm{CDCl}_{3}\right): \delta=143.3,138.6,129.7,128.1,127.3$, 124.7, 117.9, 115.7, 58.8, 48.6, 42.6, 26.1, 23.3, 21.5, 14.5.

HRMS: $m / z$ calcd for $\mathrm{C}_{17} \mathrm{H}_{22} \mathrm{NO}_{2} \mathrm{~S}[\mathrm{M}+\mathrm{H}]^{+}$: 304.1373; found: 304.1368 .

\section{(3a,7a)-2,2-Dimethyl-3-methylene-1-tosyl-2,3,3a,6,7,7a-hexahy- dro-1H-indole (4c)}

Product 4c was isolated following GP-2 as a colorless oil (32\%, 20.3 $\mathrm{mg}, 0.06 \mathrm{mmol})$ using $3 \mathrm{c}(63.5 \mathrm{mg}, 0.2 \mathrm{mmol})$ as reagent.

IR (neat): 2917, 1567, 1331, 1167, 1390, 878, 623, $555 \mathrm{~cm}^{-1}$.

${ }^{1} \mathrm{H}$ NMR $\left(300 \mathrm{MHz}, \mathrm{CDCl}_{3}\right): \delta=7.78(\mathrm{~d}, J=8.2 \mathrm{~Hz}, 2 \mathrm{H}), 7.27(\mathrm{~d}, J=4.9$ $\mathrm{Hz}, 2 \mathrm{H}), 5.90-5.50(\mathrm{~m}, 2 \mathrm{H}), 4.98(\mathrm{~d}, J=2.9 \mathrm{~Hz}, 1 \mathrm{H}), 4.78(\mathrm{~d}, J=2.4 \mathrm{~Hz}$, $1 \mathrm{H}), 3.88(\mathrm{dt}, J=9.0,6.6 \mathrm{~Hz}, 1 \mathrm{H}), 2.81$ (br s, $1 \mathrm{H}), 2.41$ (s, $3 \mathrm{H}), 2.17-$ 1.86 (m, $2 \mathrm{H}), 1.73$ (s, $3 \mathrm{H}), 1.48$ (s, $3 \mathrm{H}), 1.33-1.25$ (m, $2 \mathrm{H}$ ).

${ }^{13} \mathrm{C}$ NMR $\left(75 \mathrm{MHz}, \mathrm{CDCl}_{3}\right): \delta=157.0,142.6,129.4,129.4,127.0,123.9$, 123.8, 103.4, 67.1, 56.4, 37.8, 30.0, 29.9, 29.2, 23.5, 21.5.

LC-MS: $m / z$ calcd for $\mathrm{C}_{18} \mathrm{H}_{24} \mathrm{NO}_{2} \mathrm{~S}[\mathrm{M}+\mathrm{H}]^{+}$: 318.1; found: 318.1 .

\section{Dimethyl (3a,7a)-3-Methylene-2,3,3a,6,7,7a-hexahydro-1 $\mathrm{H}$-in- dene-1,1-dicarboxylate (4d)}

Product 4d was isolated following GP-2 as a colorless oil (70\%, 52.3 $\mathrm{mg}, 0.21 \mathrm{mmol}$ ) using 3d (75 mg, $0.3 \mathrm{mmol}$ ) as reagent.

IR (neat): 2950, 1725, 1434, 1297, 1218, 1039, 895, $701 \mathrm{~cm}^{-1}$.

${ }^{1} \mathrm{H}$ NMR $\left(300 \mathrm{MHz}, \mathrm{CDCl}_{3}\right): \delta=5.88-5.83(\mathrm{~m}, 1 \mathrm{H}), 5.77-5.72(\mathrm{~m}, 1 \mathrm{H})$, $4.97(\mathrm{~d}, J=2.2 \mathrm{~Hz}, 1 \mathrm{H}), 4.83(\mathrm{~d}, J=2.6 \mathrm{~Hz}, 1 \mathrm{H}), 3.73(\mathrm{~s}, 3 \mathrm{H}), 3.72(\mathrm{~s}, 3$ $\mathrm{H}), 3.32(\mathrm{dq}, J=17.8,2.5 \mathrm{~Hz}, 1 \mathrm{H}), 3.21$ (br s, $1 \mathrm{H}), 2.89-2.81(\mathrm{~m}, 2 \mathrm{H})$, 2.04-1.99 ( $\mathrm{m}, 2 \mathrm{H}), 1.35-1.07$ ( $\mathrm{m}, 2 \mathrm{H})$.

${ }^{13} \mathrm{C}$ NMR $\left(75 \mathrm{MHz}, \mathrm{CDCl}_{3}\right): \delta=172.3,170.2,151.1,126.5,126.4,107.6$, $62.4,52.8,52.5,43.1,42.9,37.7,24.5,21.3$.

LC-MS: $m / z$ calcd for $\mathrm{C}_{14} \mathrm{H}_{19} \mathrm{O}_{4}[\mathrm{M}+\mathrm{H}]^{+}: 251.1$; found: 251.1 .

(3a,7a,Z)-3-[2-(Cinnamyloxy)ethylidene]-2,3,3a,6,7,7a-hexahydrobenzofuran ( $4 \mathrm{e})$

Product 4e was isolated following GP-2 as a colorless oil (44\%, 37.3 $\mathrm{mg}, 0.13 \mathrm{mmol})$ using $\mathbf{3 e}(85 \mathrm{mg}, 0.3 \mathrm{mmol})$ as reagent.

IR (neat): 2924, 1735, 1449, 1170, 1039, 963, 746, $692 \mathrm{~cm}^{-1}$.

${ }^{1} \mathrm{H} \mathrm{NMR}\left(300 \mathrm{MHz}, \mathrm{CDCl}_{3}\right): \delta=7.42-7.23(\mathrm{~m}, 5 \mathrm{H}), 6.63(\mathrm{~d}, J=15.9 \mathrm{~Hz}$, $1 \mathrm{H}), 6.31(\mathrm{dt}, J=15.9,6.0 \mathrm{~Hz}, 1 \mathrm{H}), 5.79-5.75(\mathrm{~m}, 1 \mathrm{H}), 5.57-5.54(\mathrm{~m}$, $2 \mathrm{H}), 4.53(\mathrm{~d}, J=13.4 \mathrm{~Hz}, 1 \mathrm{H}), 4.38(\mathrm{~d}, J=12.5 \mathrm{~Hz}, 1 \mathrm{H}), 4.23$ (td, $J=5.7$, $2.8 \mathrm{~Hz}, 1 \mathrm{H}), 4.15(\mathrm{~d}, J=6.1 \mathrm{~Hz}, 2 \mathrm{H}), 3.98(\mathrm{~d}, J=6.6 \mathrm{~Hz}, 2 \mathrm{H}), 3.18(\mathrm{~s}, 1$ H), 2.38-2.10 (m, $1 \mathrm{H}), 2.00-1.87(\mathrm{~m}, 2 \mathrm{H}), 1.74-1.64(\mathrm{~m}, 1 \mathrm{H})$.

${ }^{13} \mathrm{C} \mathrm{NMR}\left(75 \mathrm{MHz}, \mathrm{CDCl}_{3}\right): \delta=146.5,136.6,132.6,128.5,127.7,127.0$, 126.4, 126.2, 125.9, 117.2, 76.4, 70.8, 67.7, 67.4, 43.4, 24.5, 20.0.

LC-MS: $m / z$ calcd for $\mathrm{C}_{19} \mathrm{H}_{23} \mathrm{O}_{2}[\mathrm{M}+\mathrm{H}]^{+}$: 283.2; found: 283.2 .

\section{7-Phenyl-3-tosyl-3-azabicyclo[4.1.0]hept-4-ene (2a')}

Complex A (1.7 mg, $0.9 \mathrm{mmol}, 0.6 \mathrm{~mol} \%$ ) and freshly degassed toluene $(0.5 \mathrm{~mL})$ were added under $\mathrm{N}_{2}$ to a Schlenk-type flask. Substrate 1a $(0.15 \mathrm{mmol})$ and benzoic acid $(0.15 \mathrm{mmol}, 1$ equiv) were sequentially added. The mixture was heated at $110^{\circ} \mathrm{C}$ and the conversion was followed analyzing samples via TLC. Upon complete conversion of the substrate ( $24 \mathrm{~h})$, the solution was diluted with EtOAc $(5 \mathrm{~mL})$ and purified. Product 2a' was obtained as a yellow oil; yield: $17 \mathrm{mg}$ (36\%, $0.054 \mathrm{mmol})$. Spectra correspond to the literature. ${ }^{16}$

${ }^{1} \mathrm{H} \mathrm{NMR}\left(300 \mathrm{MHz}, \mathrm{CDCl}_{3}\right): \delta=7.72(\mathrm{~d}, J=8.3 \mathrm{~Hz}, 2 \mathrm{H}), 7.39(\mathrm{~d}, J=8.0$ $\mathrm{Hz}, 2 \mathrm{H}), 7.28-7.13(\mathrm{~m}, 3 \mathrm{H}), 6.82(\mathrm{~d}, J=7.1 \mathrm{~Hz}, 2 \mathrm{H}), 6.45(\mathrm{~d}, J=8.0 \mathrm{~Hz}$, $1 \mathrm{H}), 5.53(\mathrm{dd}, J=8.0,5.4 \mathrm{~Hz}, 1 \mathrm{H}), 4.06(\mathrm{~d}, J=12.0 \mathrm{~Hz}, 1 \mathrm{H}), 3.18$ (dd, $J=12.0,2.9 \mathrm{~Hz}, 1 \mathrm{H}), 2.49(\mathrm{~s}, 3 \mathrm{H}), 1.96-1.90(\mathrm{~m}, 1 \mathrm{H}), 1.66-1.63(\mathrm{~m}, 1$ $\mathrm{H}), 1.51-1.45(\mathrm{~m}, 1 \mathrm{H})$.

\section{Funding Information}

Research on metal aromaticity was supported by Ministero dell'Istruzione, dell'Università e della Ricerca (MIUR; grant AROMA-TriP and Departments of Excellence framework).

\section{Acknowledgment}

We warmly acknowledge support from UniPr and UPMC.

\section{Supporting Information}

Supporting information for this article is available online at https://doi.org/10.1055/s-0037-1611653.

\section{References}

(1) For reviews, see: (a) Boldyrev, A. I.; Wang, L.-S. Chem. Rev. 2005, 105, 3716. (b) Tsipis, C. A. Coord. Chem. Rev. 2005, 249, 2740. (c) Mercero, J. M.; Boldyrev, A. I.; Merino, G.; Ugalde, J. M. Chem. Soc. Rev. 2015, 44, 6519. (d) Fernandez, I.; Frenking, G.; Merino, G. Chem. Soc. Rev. 2015, 44, 6452. (e) Jena, P.; Castleman, A. W. Proc. Natl. Acad. Sci. U.S.A. 2006, 103, 10560. (f) von Schleyer, P. R.; Jiao, H. J. Pure Appl. Chem. 1996, 68, 209.

(2) (a) Boldyrev, A. I.; Popov, I. A.; Starikova, A. A.; Steglenko, D. V. Chem. Eur. J. 2018, 24, 292. (b) Liu, C.; Popov, I. A.; Chen, Z.; Boldyrev, A. I.; Sun, Z.-M. Chem. Eur. J. 2018, 24, 14583. (c) Cao, C.-S.; Shi, Y.; Xu, H.; Zhao, B. Coord. Chem. Rev. 2018, 365, 122.

(3) (a) Zhai, H.-J.; Averkiev, B. B.; Zubarev, D. Y.; Wang, L.-S.; Boldyrev, A. I. Angew. Chem. Int. Ed. 2007, 46, 4277. (b) Knecht, S.; Jensen, H. J. A.; Saue, T. Nat. Chem. 2019, 11, 40.

(4) (a) Soya, T.; Mori, H.; Osuka, A. Angew. Chem. Int. Ed. 2018, 57, 15882. (b) Oh, J.; Sung, Y. M.; Kim, W.; Mori, S.; Osuka, A.; Kim, D. Angew. Chem. Int. Ed. 2016, 55, 6487. (c) Furukawa, S.; Fujita, M.; Kanatomi, Y.; Minoura, M.; Hatanaka, M.; Morokuma, K.; Ishimura, K.; Saito, M. Commun. Chem. 2018, 1, 60. (d) Saito, M.; Sakaguchi, M.; Tajima, T.; Ishimura, K.; Nagase, S.; Hada, M. Science 2010, 328, 339. (e) Ishikawa, Y.; Kimura, S.; Takase, K.; Yamamoto, K.; Kurashige, Y.; Yanai, T.; Murahashi, T. Angew. Chem. Int. Ed. 2015, 54, 2482. (f) Freitag, K.; Gemel, C.; Jerabek, P.; Oppel, M. I.; Seidel, R. W.; Frenking, G.; Banh, H.; Dilchert, K.; Fischer, R. A. Angew. Chem. Int. Ed. 2015, 54, 4370. (g) Wang, Y.; Monfredini, A.; Deyris, P.-A.; Blanchard, F.; Derat, E.; Maestri, G.; Malacria, M. Chem. Sci. 2017, 8, 7394. 
(5) (a) Wang, Y.; Deyris, P.-A.; Cañeque, T.; Blanchard, F.; Li, Y.; Bigi, F.; Maggi, R.; Blanchard, S.; Maestri, G.; Malacria, M. Chem. Eur. J. 2015, 21, 12271. (b) Blanchard, S.; Fensterbank, L.; Gontard, G.; Lacôte, E.; Maestri, G.; Malacria, M. Angew. Chem. Int. Ed. 2014, 53, 1987.

(6) (a) Lanzi, M.; Cañeque, T.; Marchio, L.; Maggi, R.; Bigi, F.; Malacria, M.; Maestri, G. ACS Catal. 2018, 8, 144. (b) Monfredini, A.; Santacroce, V.; Marchio, L.; Maggi, R.; Bigi, F.; Maestri, G.; Malacria, M. ACS Sustainable Chem. Eng. 2017, 5, 8205. (c) Monfredini, A.; Santacroce, V.; Deyris, P.-A.; Maggi, R.; Bigi, F.; Maestri, G.; Malacria, M. Dalton Trans. 2016, 45, 15786. (d) Deyris, P.-A.; Cañeque, T.; Wang, L.; Retailleau, P.; Bigi, F.; Maggi, R.; Maestri, G.; Malacria, M. ChemCatChem 2015, 7, 3266. Isolobal analogues can trigger unusual Suzuki and Kumada couplings: (e) Fu, F.; Xiang, J.; Cheng, H.; Cheng, L.; Chong, H.; Wang, S.; Li, P.; Wei, S.; Zhu, M.; Li, Y. ACS Catal. 2017, 7, 1860. (f) Diehl, C. J.; Scattolin, T.; Englert, U.; Schoenebeck, F. Angew. Chem. Int. Ed. 2019, 58, 211.

(7) (a) Fürstner, A.; Davies, P. W.; Gress, T. J. Am. Chem. Soc. 2005, 127, 8244. (b) Mamane, V.; Gress, T.; Krause, H.; Fürstner, A. J. Am. Chem. Soc. 2004, 126, 8654. (c) Fürstner, A.; Stelzer, F.; Szillat, H. J. Am. Chem. Soc. 2001, 123, 11863. (d) Fürstner, A.; Szillat, H.; Stelzer, F. J. Am. Chem. Soc. 2000, 122, 6785.

(8) (a) Nevado, C.; Echavarren, A. M. Chem. Eur. J. 2005, 11, 3155. (b) Nevado, C.; Ferrer, C.; Echavarren, A. M. Org. Lett. 2004, 6, 3191. (c) Méndez, M.; Mũnoz, M. P.; Echavarren, A. M. J. Am. Chem. Soc. 2000, 122, 11549.

(9) For selected reviews, see: (a) Fürstner, A. Chem. Soc. Rev. 2009, 38, 3208. (b) Fürstner, A.; Davies, P. W. Angew. Chem. Int. Ed. 2007, 46, 3410. (c) Blaszykowski, C.; Harrak, Y.; Brancour, C.; Nakama, K.; Dhimane, A.-L.; Fensterbank, L.; Malacria, M. Synthesis 2007, 2037. (d) Zhang, L.; Sun, J.; Kozmin, S. A. Adv. Synth. Catal. 2006, 348, 2271. For a seminal contribution, see: (e) Chatani, N.; Inoue, H.; Ikeda, T.; Murai, S. J. Org. Chem. 2000, 65, 4913. (f) Zriba, R.; Gandon, V.; Aubert, C.; Fensterbank, L.;
Malacria, M. Chem. Eur. J. 2008, 14, 1482. (g) Marion, F.; Coulomb, J.; Courillon, C.; Fensterbank, L.; Malacria, M. Org. Lett. 2004, 6, 1509. (h) Harrak, Y.; Blaszykowski, C.; Bernard, M.; Cariou, K.; Mainetti, E.; Mouriès, V.; Dhimane, A.-L.; Fensterbank, L.; Malacria, M. J. Am. Chem. Soc. 2004, 126, 8656. (i) Mainetti, E.; Mouriès, V.; Fensterbank, L.; Malacria, M.; Marco-Contelles, J. Angew. Chem. Int. Ed. 2002, 41, 2132. For recent examples, see: (j) Jullien, H.; Brissy, D.; Sylvain, R.; Retailleau, P.; Naubron, J.-V.; Gladiali, S.; Marinetti, A. Adv. Synth. Catal. 2011, 353, 1109. (k) Ni, Z.; Giordano, L.; Tenaglia, A. Chem. Eur. J. 2014, 20, 11703. (l) Pradal, A.; Gladiali, S.; Michelet, V.; Toullec, P. Y. Chem. Eur. J. 2014, 20, 7128.

(10) For recent examples of cycloisomerizations with palladium, see: (a) Qiu, Y.-A.; Yang, B.; Jiang, T.; Zhu, C.; Backvall, J.-E. Angew. Chem. Int. Ed. 2017, 56, 3221. (b) Petrone, D. A.; Franzoni, I.; Ye, J.; Rodriguez, J. F.; Poblador-Bahamonde, A. I.; Lautens, M. J. Am. Chem. Soc. 2017, 139, 3546. For reviews, see: (c) Düfert, A.; Werz, D. B. Chem. Eur. J. 2016, 22, 16718. (d) Tietze, L. F.; Kinzel, T. Pure Appl. Chem. 2007, 79, 629.

(11) (a) Cera, G.; Lanzi, M.; Balestri, D.; Della Ca', N.; Maggi, R.; Bigi, F.; Malacria, M.; Maestri, G. Org. Lett. 2018, 20, 3220. (b) Cera, G.; Lanzi, M.; Bigi, F.; Maggi, R.; Malacria, M.; Maestri, G. Chem. Commun. 2018, 54, 14021. (c) Rodriguez, J. F.; Burton, K. I.; Franzoni, I.; Petrone, D. A.; Scheipers, I.; Lautens, M. Org. Lett. 2018, 20, 6915. (d) Haydl, A. M.; Breit, B.; Lang, T.; Krische, M. J. Angew. Chem. Int. Ed. 2017, 56, 11312. (e) Peacock, M. D.; Roos, C. B.; Hartwig, J. F. ACS Cent. Sci. 2016, 2, 647.

(12) (a) Trost, B. M. Acc. Chem. Res. 1990, 23, 34. (b) Trost, B. M.; Lautens, M. J. Am. Chem. Soc. 1985, 107, 1781.

(13) Gorin, D. J.; Toste, F. D. Nature 2007, 446, 395.

(14) Hashmi, A. S. K. Acc. Chem. Res. 2014, 47, 864.

(15) Johnson, J. A.; Petersen, B. M.; Kormos, A.; Echeverría, E.; Chen, Y.-S.; Zhang, J. J. Am. Chem. Soc. 2016, 138, 10293.

(16) Wang, W.; Yang, J.; Wang, F.; Shi, M. Organometallics 2011, 30, 3859. 